RESEARCH ARTICLE

\title{
LAND SUITABILITY EVALUATION FOR UPLAND RICE IN TIRTOMOYO DISTRICT, WONOGIRI REGENCY, INDONESIA
}

\author{
Nur Aida Suheri, Mujiyo, and Hery Widijanto \\ Department of Soil Science, Faculty of Agriculture, Universitas Sebelas Maret \\ Jl. Ir Sutami 36A, Surakarta, Jawa Tengah \\ Submitted : 2017-08-01 Accepted : 2018-04-07
}

\begin{abstract}
Food cultivation, especially upland rice is needed to fulfill the needs of dryland food. It is necessary to evaluate the suitability of the land so that it can overcome land constraints to increase the productivity of upland rice in Tirtomoyo Regency. The unit of analysis is Soil Mapping Unit based on soil type map using ArcGIS 10.1 and determination of sample point based on purposive sampling method. Data analysis was done by matching between the result of soil characteristic which has been obtained with growth requirement of the upland rice. Based on the results, District Tirtomoyo divided into 4 Soil Mapping Unit. The actual land suitability class for upland rice is moderately suitable (S2) and not suitable (N). Limiting factors include rainfall, slope, erosion hazard, basic saturation, $\mathrm{CEC}, \mathrm{C}$-organic, $\mathrm{N}$ total, $\mathrm{K}_{2} \mathrm{O}$. Improvement efforts are done by arranging cropping pattern, drainage management, a making of terracing, cover crop planting, implementing organic material, and fertilizing. The suitability class of potential land of upland rice is highly suitable (S1) and marginally suitable (S3).
\end{abstract}

Keywords: land suitability, soil mapping unit, upland rice

How to Cite: Suheri, N.A., Mujiyo, Widijanto, H. (2018). Land Suitability Evaluation for Upland Rice in Tirtomoyo District, Wonogiri Regency, Indonesia. Sains Tanah Journal of Soil Science and Agroclimatology, 15(1): 46-53 (doi: 10.15608/stjssa.v15i1.21670)

Permalink/DOI: http://dx.doi.org/10.15608/stjssa.v15i1.21670

\section{INTRODUCTION}

Many of paddy fields are switching functions for non-agricultural, then the potential of dry land can be used for food cultivation especially upland rice required to fulfill food necessary in Indonesia. The area of upland rice cultivation in Indonesia is about 1.12 million ha or only $10 \%$ of the national rice yield area (Toha, 2006). Tirtomoyo District has a productivity of upland rice in 2013 was 4.49 tons ha- ${ }^{-1}$ and decreased in 2014 to 4.47 tons ha ${ }^{-1}$ and 2015 to 4.67 tons $\mathrm{ha}^{-1}$ (BPS, 2016). The main constraints on dry land used for the

\footnotetext{
* Corresponding Author :

Email:nuraidashr@gmail.com
}

cultivation of upland rice has a low fertility rate (Dariah \& Las, 2010). Montgomery et al. (2017) also said that upland areas for agriculture show limited plant diversity due to decreased soil fertility.

It is necessary to evaluate the suitability of land that it can resolve the constraints on the land to improve the productivity of upland rice in Tirtomoyo District. Evaluation of land suitability is useful to obtain information on the appropriate land characteristics and can be known class suitability of land and limiting factors. It can be determined the level of management required for land can be used sustainably by existing obstacles or threats (Ritung, Nugroho, Mulyani, \& Suryani, 2011; 
Syafruddin, Kairupan, \& Saidah, 2004). This study aimed to evaluate the suitability of land for upland rice cultivation in Tirtomoyo District of Wonogiri Regency. It attempts to fill the knowledge gap with new data for soil suitability in Tirtomoyo agriculture.

\section{MATERIALS AND METHOD}

\section{Description of the study area}

The study area is Tirtomoyo District, Wonogiri Regency, Central Java Provinces. The geographical location is in UTM zone $49 \mathrm{~S}\left(111^{\circ}\right.$

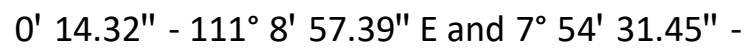
$8^{\circ} 0^{\prime} 54.03 "$ S) covering $10,409.61$ ha with elevation ranges from 150 to $1,100 \mathrm{~m}$ above mean sea level. The mean of annual rainfall per 10 years (2006-2015) is $2,119.9 \mathrm{~mm}$ year ${ }^{-1}$. Temperature ranges between $21.2^{\circ} \mathrm{C}-24.8^{\circ} \mathrm{C}$. The location is surrounded by hills and its territory is divided into 2 areas which are traversed by Wiroko River.

\section{Pra-survey}

The unit of analysis is Soil Mapping Unit (SMU) that based on uniformity of soil type, slope, topography, and parent material of Tirtomoyo District using ArcGIS 10.1 software. Determination of sample points of each SMU based on purposive sampling is intentional, proportional, and representative area. A total of 12 sample points were taken off 4 SMU in the study area was investigated. Drainage determined by looking directly at soil color, rust (iron, aluminum, manganese), and gley color (reduction) on the surface layer to a depth of $100 \mathrm{~cm}$. Soil depth determined by measuring depth which is classified as very shallow (less than $20 \mathrm{~cm}$ ), shallow $(20 \mathrm{~cm}-50$ $\mathrm{cm})$, moderately deep $(50 \mathrm{~cm}-75 \mathrm{~cm})$, deep (more than $75 \mathrm{~cm}$ ). Slope determined using clinometer. Erosion determined by looking directly on the soil surface of sheet erosion, reel erosion, and gully erosion. Surface stoniness and surface outcrops determined by looking directly rocks in the soil surface and rocks that are exposed to the soil surface. Surface soil depths $(0-20 \mathrm{~cm})$ were collected of each sampling points for laboratory analysis.

\section{Laboratory analysis}

The soil samples that have been collected from the field were air-dried and then filtered using a $2 \mathrm{~mm}$ sieve filter. Particles less than $2 \mathrm{~mm}$ are used for physicochemical analysis following procedures given by (BPT, 2009). Particle size distribution was determined by pipette method. Soil reaction $(\mathrm{pH})$ and electrical conductivity $(\mathrm{EC})$ were measured in 1:2.5 soil-water suspension, $\mathrm{pH}$ determined using $\mathrm{pH}$ meter and EC determined using conductivity meter. Organic carbon was determined by the Walkley and Black method. Total nitrogen (N) was determined by micro-Kjeldahl digestion method. The potential $\mathrm{P}_{2} \mathrm{O}_{5}$ and $\mathrm{K}_{2} \mathrm{O}$ contents were extracted with $\mathrm{HCl}$ $25 \%$. Cation exchange capacity (CEC) determined by $1 \mathrm{~N} \mathrm{NH}_{4} \mathrm{OAc} \mathrm{pH} 7.0$ (ammonium acetate) method. Exchangeable cations ( $\mathrm{Ca}, \mathrm{Mg}$, $\mathrm{Na}$ and $\mathrm{K}$ ) were extracted with $1 \mathrm{~N} \quad \mathrm{NH}_{4} \mathrm{OAc} \quad \mathrm{pH} 7.0$ (ammonium acetate). Base saturation was calculated by the summation of exchangeable cations. Exchangeable sodium percentage (ESP) was determined by comparing the value of $\mathrm{Na}^{+}$ with CEC.

\section{Land suitability evaluation}

Land suitability evaluation was carried out using the FAO (1976) as modified by (Wahyunto et al., 2016). Each SMU were first placed in suitability classes by matching the land/soil requirements for upland rice (Table 1) with the characteristics of the SMU (Table 2). Nineteen parameters have been used in this work to study land suitability for upland rice. These parameters are air temperature, annual rainfall, drainage, soil texture, coarse material, soil depth, $\mathrm{CEC}$, base saturation, $\mathrm{pH}$, organic carbon, total nitrogen, potential $\mathrm{P}_{2} \mathrm{O}_{5}$ and $\mathrm{K}_{2} \mathrm{O}$, electrical conductivity (EC), exchangeable sodium percentage (ESP), slope, erosion, surface stoniness, and surface outcrops. 
Table 1. Soil requirements for upland rice

\begin{tabular}{|c|c|c|c|c|}
\hline Land characteristic & S1 & S2 & S3 & $\mathbf{N}$ \\
\hline \multicolumn{5}{|l|}{ Temperature (tc) } \\
\hline \multirow[t]{2}{*}{ Mean temperature $\left({ }^{\circ} \mathrm{C}\right)$} & $24-29$ & $22-24$ & $18-22$ & $<18$ \\
\hline & & $29-32$ & $32-35$ & $>35$ \\
\hline \multicolumn{5}{|l|}{ Water availability (wa) } \\
\hline $\begin{array}{l}\text { Mean annual rainfall } \\
\left(\mathrm{mm}^{2} \text { year }^{-1}\right)\end{array}$ & $1,500-2,000$ & $\begin{array}{l}1,000-<1,500 \\
>2,000-2,500\end{array}$ & $\begin{array}{c}700-<1,000 \\
>2,500-3,000\end{array}$ & $\begin{array}{l}<700 \\
>3,000\end{array}$ \\
\hline \multicolumn{5}{|l|}{ Rooting condition (rc) } \\
\hline Drainage & good, better & $\begin{array}{c}\text { slightly fast, } \\
\text { slightly hampered }\end{array}$ & $\begin{array}{l}\text { hampered, } \\
\text { very hampered }\end{array}$ & fast \\
\hline Texture & $\begin{array}{c}\mathrm{SC}, \mathrm{C}, \mathrm{SiC} \\
\mathrm{CL}, \mathrm{SCL}, \mathrm{SiCL}\end{array}$ & L, SiL, Si & SL & $S, L S$ \\
\hline Coarse material (\%) & $<15$ & $15-35$ & $35-55$ & $>55$ \\
\hline Soil depth (cm) & $>50$ & $40-50$ & $25-40$ & $<25$ \\
\hline \multicolumn{5}{|l|}{ Nutrient retention $(\mathrm{nr})$} \\
\hline $\mathrm{CEC}(\mathrm{cmol})$ & $>16$ & $5-16$ & $<5$ & - \\
\hline Base saturation (\%) & $>35$ & $20-35$ & $<20$ & - \\
\hline \multirow[t]{2}{*}{$\mathrm{pH} \mathrm{H}_{2} \mathrm{O}$} & $5.5-7.5$ & $5.0-5.5$ & $<5.0$ & - \\
\hline & & 7.5- 8.0 & $>8.0$ & \\
\hline Organic carbon (\%) & $>1.2$ & $0.8-1.2$ & $<0.8$ & - \\
\hline \multicolumn{5}{|l|}{ Nutrient availability (na) } \\
\hline Total nitrogen (\%) & $0.21-0.50$ & $0.10-0.20$ & $<0.10$ & - \\
\hline $\mathrm{P}_{2} \mathrm{O}_{5}\left(\mathrm{mg} 100^{-1} \mathrm{~g}^{-1}\right)$ & $41-60$ & $21-40$ & $15-20<15$ & - \\
\hline $\mathrm{K}_{2} \mathrm{O}\left(\mathrm{mg} 100^{-1} \mathrm{~g}^{-1}\right)$ & $21-40$ & $10-20$ & $<10$ & - \\
\hline \multicolumn{5}{|l|}{ Toxicity (xc) } \\
\hline Salinity (dS m $\mathrm{m}^{-1}$ ) & $<2$ & 2- 4 & 4- 6 & $>6$ \\
\hline \multicolumn{5}{|l|}{ Sodicity (xn) } \\
\hline Alkalinity/ESP (\%) & $<20$ & 20- 30 & $30-40$ & $>40$ \\
\hline \multicolumn{5}{|l|}{ Erosion hazard (eh) } \\
\hline Slope (\%) & $<3$ & 3- 8 & 8- 15 & $>15$ \\
\hline Erosion & & very light & light - moderate & $\begin{array}{l}\text { heavy- } \\
\text { very heavy }\end{array}$ \\
\hline \multicolumn{5}{|l|}{ Land preparation (Ip) } \\
\hline Surface stoniness (\%) & $<5$ & $5-15$ & $15-40$ & $>40$ \\
\hline Surface outcrops (\%) & $<5$ & $5-15$ & $15-25$ & $>25$ \\
\hline
\end{tabular}

Source: Wahyunto et al. (2016) 
Table 2. Land characteristic and actual land suitability assessment of Soil Mapping Unit (SMU) in Tirtomoyo District for upland rice

\begin{tabular}{|c|c|c|c|c|c|c|c|c|}
\hline \multirow{2}{*}{ Land characteristic } & \multicolumn{2}{|l|}{ SMU 1} & \multicolumn{2}{|l|}{ SMU 2} & \multicolumn{2}{|l|}{ SMU 3} & \multicolumn{2}{|l|}{ SMU 4} \\
\hline & Value & Cs & Value & Cs & Value & Cs & Value & Cs \\
\hline \multicolumn{9}{|l|}{$\overline{T e m p e r a t u r e ~(t c)}$} \\
\hline Mean temperature $\left({ }^{\circ} \mathrm{C}\right)$ & 23 & S2 & 24.8 & S1 & 24.8 & S1 & 21.2 & S3 \\
\hline \multicolumn{9}{|l|}{ Water availability (wa) } \\
\hline $\begin{array}{l}\text { Mean annual rainfall } \\
\left(\mathrm{mm}^{\prime} \text { year }^{-1}\right)\end{array}$ & $2,119.9$ & S2 & $2,119.9$ & S2 & $2,119.9$ & S2 & $2,119.9$ & S2 \\
\hline \multicolumn{9}{|l|}{ Rooting condition (rc) } \\
\hline Drainage & good & S1 & good & S1 & good & S1 & good & S1 \\
\hline Texture & $\mathrm{CL}$ & S1 & $\mathrm{SiCL}$ & S1 & $\mathrm{SiC}$ & S1 & C & S1 \\
\hline Coarse material (\%) & $<3$ & S1 & $<3$ & S1 & $<3$ & S1 & $<3$ & S1 \\
\hline Soil depth (cm) & $>150$ & S1 & $>150$ & S1 & $>150$ & S1 & $>150$ & S1 \\
\hline \multicolumn{9}{|l|}{ Nutrient retention $(\mathrm{nr})$} \\
\hline $\mathrm{CEC}(\mathrm{cmol})$ & $17.22 \pm 1.62$ & S1 & $15.65 \pm 0.65$ & S2 & $15.92 \pm 1.55$ & S2 & $17.37 \pm 1.37$ & S1 \\
\hline Base saturation (\%) & $21.7 \pm 3.31$ & S2 & $19.49 \pm 3.26$ & S3 & $23.60 \pm 1.03$ & S2 & $24.40 \pm 1.62$ & S2 \\
\hline $\mathrm{pH} \mathrm{H} \mathrm{H}_{2} \mathrm{O}$ & $5.4 \pm 0.02$ & S2 & $5.7 \pm 0.02$ & S1 & $5.9 \pm 0.02$ & S1 & $5.3 \pm 0.09$ & S2 \\
\hline Organic carbon (\%) & $0.7 \pm 0.07$ & S3 & $1.3 \pm 0.06$ & S1 & $0.8 \pm 0.05$ & S2 & $0.8 \pm 0.08$ & $\mathrm{~S} 2$ \\
\hline \multicolumn{9}{|l|}{ Nutrient availability (na) } \\
\hline Total nitrogen (\%) & $0.18 \pm 0.01$ & $\mathrm{~S} 2$ & $0.23 \pm 0.02$ & S1 & $0.19 \pm 0.01$ & S2 & $0.21 \pm 0.02$ & S1 \\
\hline $\mathrm{P}_{2} \mathrm{O}_{5}\left(\mathrm{mg} 100^{-1} \mathrm{~g}^{-1}\right)$ & $17 \pm 0.33$ & S3 & $28 \pm 1.00$ & S2 & $41 \pm 0.94$ & S1 & $14 \pm 0.53$ & S3 \\
\hline $\mathrm{K}_{2} \mathrm{O}\left(\mathrm{mg} 100^{-1} \mathrm{~g}^{-1}\right)$ & $18 \pm 0.69$ & S2 & $23 \pm 2.14$ & S1 & $14 \pm 0.04$ & S2 & $13 \pm 0.67$ & S2 \\
\hline \multicolumn{9}{|l|}{ Toxicity (xc) } \\
\hline Salinity $\left(\mathrm{dS} \mathrm{m}^{-1}\right)$ & $0.041 \pm 0.00$ & S1 & $0.088 \pm 0.00$ & S1 & $0.094 \pm 0.01$ & S1 & $0.045 \pm 0.00$ & S1 \\
\hline \multicolumn{9}{|l|}{ Sodicity (xn) } \\
\hline Alkalinity/ESP (\%) & $0.84 \pm 0.06$ & S1 & $1.19 \pm 0.07$ & S1 & $1.14 \pm 0.08$ & S1 & $0.61 \pm 0.06$ & S1 \\
\hline \multicolumn{9}{|l|}{ Erosion hazard (eh) } \\
\hline Slope (\%) & $>40$ & $\mathbf{N}$ & $25-40$ & $\mathbf{N}$ & $3-5$ & S2 & $15-25$ & $\mathbf{N}$ \\
\hline Erosion & heavy & $\mathbf{N}$ & moderate & S3 & very light & S2 & moderate & S3 \\
\hline \multicolumn{9}{|l|}{ Land preparation (Ip) } \\
\hline Surface stoniness (\%) & $<5$ & s1 & $<5$ & S1 & $<5$ & S1 & $<5$ & S1 \\
\hline Surface outcrops (\%) & $<5$ & S1 & $<5$ & S1 & $<5$ & S1 & $<5$ & S1 \\
\hline Land Suitability Class & N-eh1,eh & & N-eh1 & & $\begin{array}{r}\text { S2-wa1,nr1, } \\
\text { nr4,na1, } \\
\text { eh1,eh2 }\end{array}$ & & N-eh1 & \\
\hline
\end{tabular}

$\mathrm{Cs}=$ Class, $\mathrm{CL}=$ clay loam, $\mathrm{SiCL}=$ silty clay loam, $\mathrm{SiC}=$ silty clay, $\mathrm{C}=$ clay, $\mathrm{CEC}=$ cation exchange capability, $\mathrm{N}$ $=$ not suitable, $\mathrm{S} 1=$ highly suitable, $\mathrm{S} 2$ = moderately suitable, $\mathrm{S} 3=$ marginally suitable, wa 1 = Annual rainfall, $\mathrm{nr} 1=\mathrm{CEC}, \mathrm{nr} 2=$ Base saturation, $\mathrm{nr} 4=$ Organic carbon, na1 $=$ Total nitrogen, na3 $=\mathrm{K}_{2} \mathrm{O}$, eh1 $=$ Slope, eh2 $=$ Erosion

\section{RESULTS AND DISCUSSION}

Actual land suitability is the suitability for a defined use of land in its present condition, without major improvements (FAO 1976). Based on matching result between land characteristic on soil mapping unit with land suitability for upland rice in Tirtomoyo District (Table 2), land suitability for upland rice is moderately suitable (S2) and not suitable (N). These limiting factors are slope (eh1), erosion (eh2), annual rainfall (wa1), CEC (nr1), base saturation ( $n r 2)$, carbon organic ( $n r 4)$, total nitrogen (na1), and $\mathrm{K}_{2} \mathrm{O}$ (na3).

In the not suitable class $(\mathrm{N})$ with an area of 3,569.65 ha (34.29\%) in SMU 1 has a slope and erosion hazard as a limiting factor, whereas SMU 2 and SMU 4 with the total. 


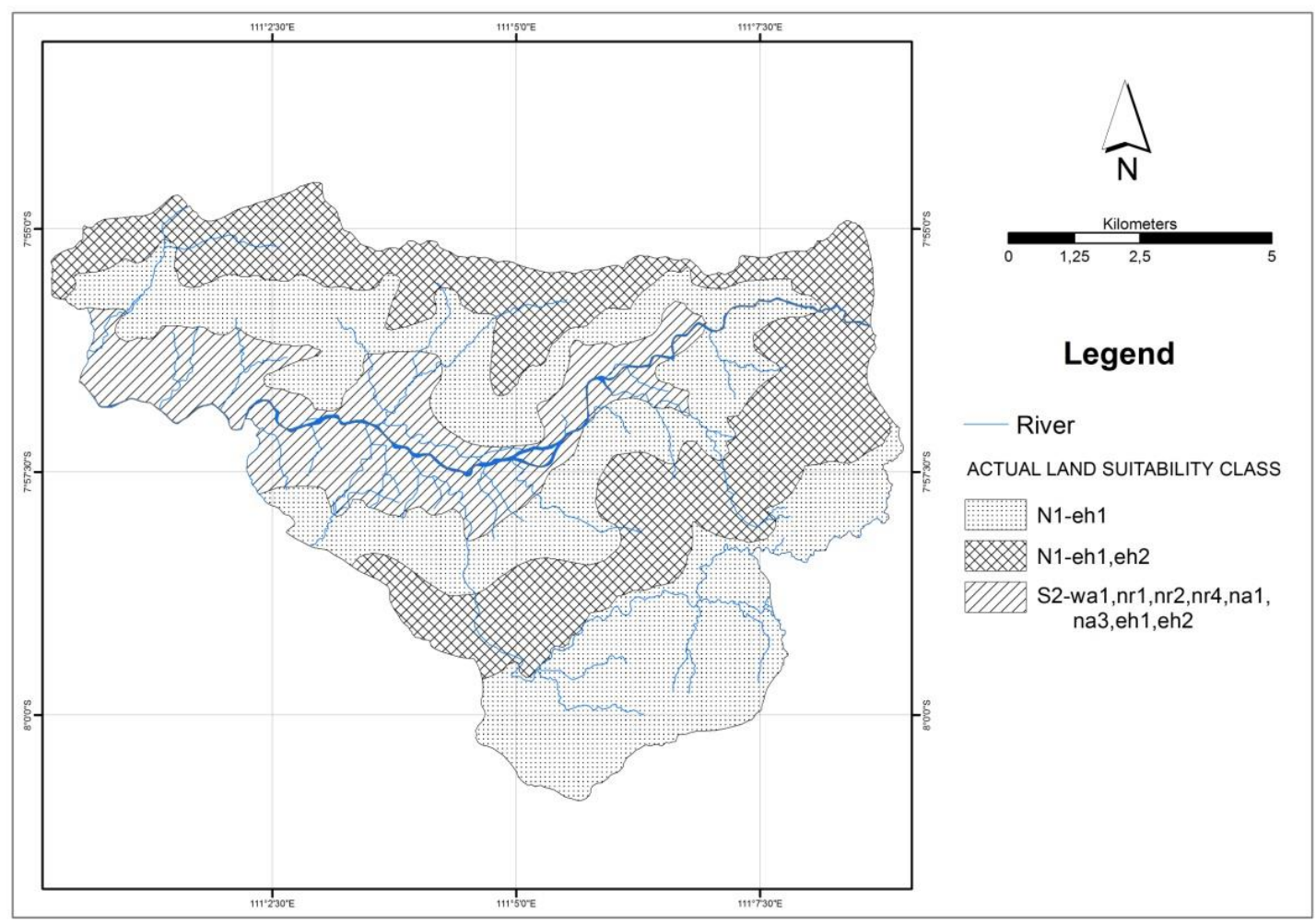

Figure 1. Map of actual land suitability for upland rice

area of $4,809.27 \mathrm{Ha}(46.20 \%)$ have a slope as a limiting factor. Efforts that can be done to overcome these limiting factors is by making terracing and planting a cover crop Terraces that can be used to reduce erosion are with bench terraces, as they are effective in controlling erosion and surface flow. As noted by (Arsyad, 1989) that serves to reduce the length of the terrace slopes and hold water, thus reducing the speed and amount of runoff and allow water absorption by the soil, so erosion reduced. Cover crops can also be used to reduce erosion hazards by using leguminous / legume cover crop (LCC). Langdale et al. (1991) state that the main function of a cover crop is to prevent land degradation by wind erosion or water erosion.

Moderately suitable class (S2) with an area of 2,030.72 ha (19.51\%) in SMU 3 has a rainfall $\left(2,119.9 \mathrm{~mm}\right.$ year $\left.{ }^{-1}\right)$ as a limiting factor. Efforts that can be done to overcome the high rainfall limiting factor is to set the planting rotation. Planting rotation is done to avoid the development of the pest cycle. As Bruns (2012) points out that one of the main benefits of cropping rotation is a pest crop breaker. Another effort that can be done is by managing the drainage of land or drainage channel because the upland rice is managed on dry soil, without inundation.

The improvement efforts of base saturation, CEC, and carbon organic limiting factors are done by addition of organic material. The dose of organic matter needed as much as 5 ton ha ${ }^{-1}$ per planting season. As Zhang \& He (2004) point out that liming and giving organic fertilizers can increase the base saturation. Provision of organic materials can increase the amount of saturation of the base because of organic matter related to CEC, and CEC also affects the size of the base saturation. Aduayi (1985) in Ugboma (2016) stated that in general rice cultivation requires soil CEC ranged from 12 - $25 \mathrm{cmol}(+) \mathrm{kg}^{-1}$. Provision of organic materials can be direct with the provision of plant litter into the soil or with green manure, manure fertilizer, and organic fertilizer. Organic matter usually accumulates more in the first $20 \mathrm{~cm}$ of the soil surface (Ugboma 2016). The limiting factors of $\mathrm{N}$-total and $\mathrm{K}_{2} \mathrm{O}$ can be accomplished by fertilization. Fertilization is done to provide additional nutrients to the soil to increase nutrient content for plants. 
Suheri et al. / SAINS TANAH - Journal of Soil Science and Agroclimatology, 15(1), 2018, 51

Table 3 Efforts to improve the suitability class of upland rice

\begin{tabular}{clllcc}
\hline \multirow{2}{*}{ SMU } & \multicolumn{1}{c}{ Land Suitability Class } & \multicolumn{2}{c}{ Area } \\
\cline { 2 - 6 } & \multicolumn{1}{c}{ Actual } & \multicolumn{1}{c}{ Efforts } & \multicolumn{1}{c}{ Potential } & Ha & \% \\
\hline 1 & N-eh1,eh2 & - making terracing & S3-eh1,eh2 & $3.569,65$ & 34.29 \\
& & - planting a cover crop & & & \\
2 & N-eh1 & - making terracing & S3-eh1 & $2.880,11$ & 27.67 \\
3 & S2-wa1,nr1, & - set the planting rotation & S1 & $2.030,72$ & 19.51 \\
& nr2,nr4,na1, & - drainage management & & & \\
& na3,eh1,eh2 & - addition of organic material & & & \\
& & - addition of fertilizer & & & \\
& & - making terracing & & & \\
& & - planting a cover crop & S3-tc1,eh1 & $1.929,16$ & 18.53 \\
\hline
\end{tabular}

$\mathrm{N}=$ not suitable, $\mathrm{S} 1$ = highly suitable, $\mathrm{S} 2$ = moderately suitable, $\mathrm{S} 3$ = marginally suitable, wa1 = Annual rainfall, $\mathrm{nr} 1=\mathrm{CEC}, \mathrm{nr} 2=$ Base saturation, $\mathrm{nr} 4=$ Organic carbon, na1 = Total nitrogen, na3 $=K_{2} \mathrm{O}$, eh1 $=$ Slope, eh2 $=$ Erosion

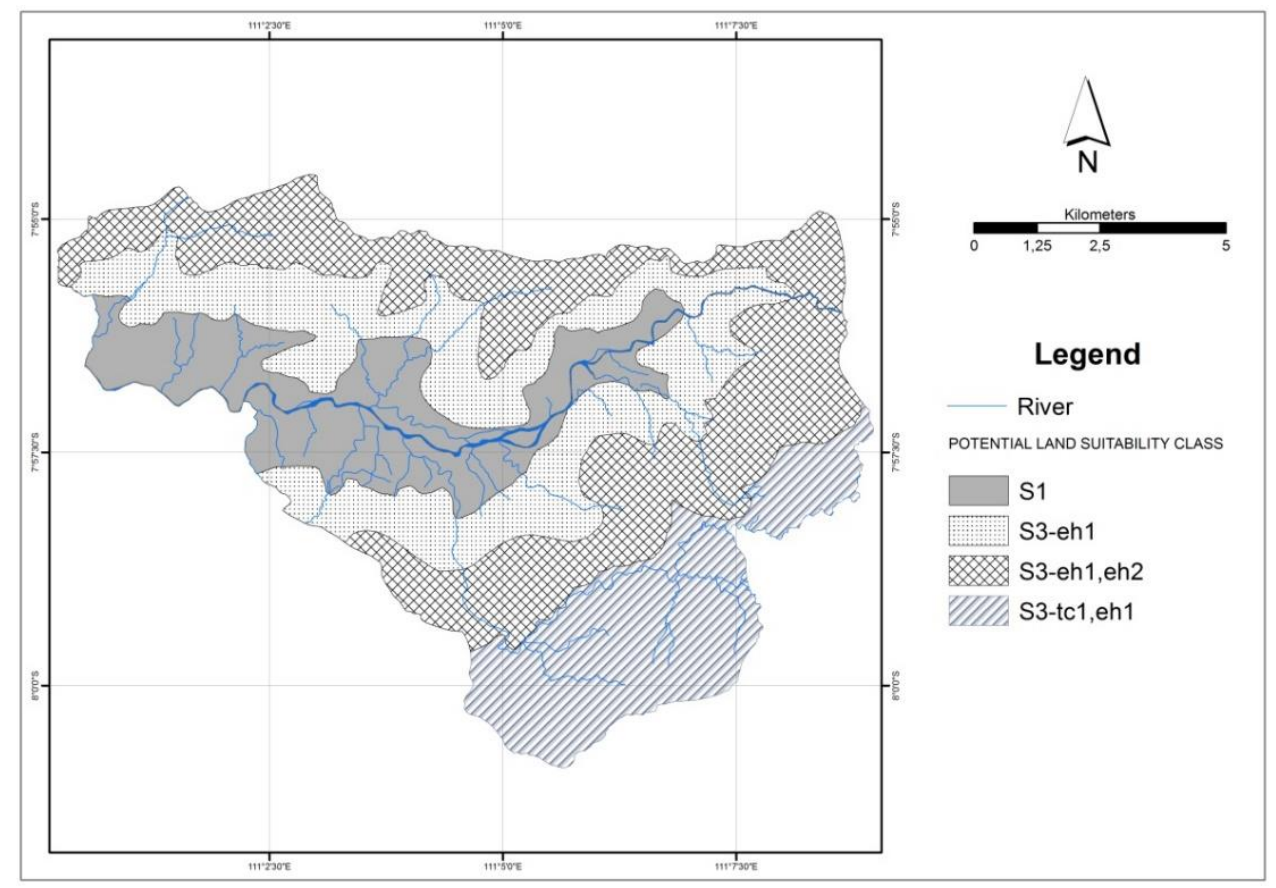

Figure 2. Map of potential land suitability for upland rice

Potential land suitability is the suitability, for a defined use, of land units in their condition at some future date, after specified major improvements have been completed where necessary (FAO, 1976). After improvement efforts on each limiting factor for upland rice, the potential land suitability class presented in Table 3 is shown.

The potential land suitability class for upland rice is highly suitable (S1) and marginally suitable (S3). Class S1 (SMU 3) has an area of 2,030.72 ha (19.51\%). Improvement of a land characteristic is the arrangement of cropping rotation, management of drainage, an addition of organic material, fertilizing, making terracing and planting a cover crop. Class S3-eh1 (SMU 2) has an area of 2880.11 ha (27.67\%). Class S3-eh1,eh2 (SMU 1) has an area of 3,569.65 ha (34.29\%). Class S3-tc1,eh2 (SMU 4) has an area of $1,929.16$ ha (18.53\%). Improvement of a land characteristic is made of terracing and planting cover crop. 


\section{CONCLUSION}

Tirtomoyo District consists of 4 SMU has the actual land suitability class of upland rice is moderately suitable (S2) and not suitable (N). The limiting factors are rainfall, soil CEC, base saturation, carbon organic, total nitrogen, $\mathrm{K}_{2} \mathrm{O}$, slope, and erosion. Efforts that can be done to overcome the limiting factor is to regulate the rotation of planting, land drainage management, provision of organic materials, fertilization, making the terrace and planting a cover crop. So that the suitability class of potential land of upland rice becomes highly suitable (S1) and marginally suitable (S3).

\section{ACKNOWLEDGMENT}

The research study and the paper writing were supported by Sebelas Maret University Surakarta under the research grant PNPB UNS 2016-2017.

\section{REFERRENCES}

Arsyad, S. (1989). Konservasi Tanah dan Air. Bogor: IPB Press. Retrieved from http://repository.ipb.ac.id/handle/12345 $6789 / 42667$

BPS. (2016). Kecamatan Tirtomoyo Dalam Angka 2016. Wonogiri. Retrieved from https://wonogirikab.bps.go.id/publicatio n/2016/07/29/6489219ecaaebc5bc6dc6 cb4/kecamatan-tirtomoyo-dalam-angka2016.html

BPT. (2009). Petunjuk Teknis Analisis Kimia Tanah, Tanaman, Air dan Pupuk. (F. Agus, Ed.), Balai Penelitian tanah (2nd ed.). Bogor: Balai Penelitian Tanah. https://doi.org/10.1007/s13398-0140173-7.2

Bruns, H. A. (2012). Concepts in Crop Rotations. In G. Aflakpui (Ed.), Agriculture Science (p. 252). Rijeka, Croatia: InTech. https://doi.org/http://dx.doi.org/10.577 2/46845

Dariah, A., \& Las, I. (2010). Ekosistem Lahan Kering Sebagai Pendukung Pembangunan Pertanian. Membalik Kecenderungan Degradasi Sumberdaya Lahan Dan Air.
Bogor: Badan Penelitian dan Pengembangan Pertanian. Retrieved from

http://new.litbang.pertanian.go.id/buku/ membalik-kecenderungan-degrad/BABIII-2.pdf

FAO. (1976). A framework for land evaluation. FAO soils bulletin $n$.32. https://doi.org/M51

Langdale, G. W., Blevins, R. L., Karlen, D. L., McCool, D. K., Nearing, M. a., Skidmore, E. L., ... Williams, J. R. (1991). Cover crop effects on soil erosion by wind and water. Cover Crops for Clean Water, 15-22. https://doi.org/10.1111/j.13653059.2010.02409.x

Montgomery, S., Guppy, C., Martin, R., Wright, G., Flavel, R., Phan, S., ... Tighe, M. (2017). Productivity and profitability of upland crop rotations in Northwest Cambodia. Field Crops Research, 203, 150-162. https://doi.org/10.1016/j.fcr.2016.12.01 0

Ritung, S., Nugroho, K., Mulyani, A., \& Suryani, E. (2011). Petunjuk Teknis Evaluasi Lahan untuk Komoditas Pertanian (edisi Revisi. Bogor: Balai Besar Penelitian dan Pengembangan Sumberdaya Lahan Pertanian, Badan Penelitian dan Pengembangan Pertanian.

Syafruddin, Kairupan, N. ., \& Saidah. (2004). Potential and evaluation of land suitability for vegetable crops in Palu valley, Donggala, Central Sulawesi (Indonesia). Jurnal Agroland, 11(2), 129$135 . \quad$ Retrieved from http://agris.fao.org/agrissearch/search.do?recordID=ID20070000 89

Toha, H. M. (2006). Pengembangan Padi Gogo Mengatasi Rawan Pangan Wilayah Marginal. Prospek Pertanian Lahan Kering Dalam Mendukung Ketahanan Pangan. Bogor: Badan Penelitian dan Pengembangan Pertanian. Retrieved from

http://www.litbang.pertanian.go.id/buk u/Lahan-Kering-Ketahan/BAB-III-4.pdf

Ugboma, P. P. 2016. Effects of Rice Cultivation on Ndokwa East Grassland Soils in Delta State, Nigeria. African Journal of 
Suheri et al. / SAINS TANAH - Journal of Soil Science and Agroclimatology, 15(1), 2018, 53

Geography and Regional Planning, 3(2), 226-229.

Wahyunto, Hilmatullah, Suryani, E., Tafakresnanto, C., Ritung, S., Mulyani, A., ... Nursyamsi. (2016). Petunjuk Teknis Pedoman Penilaian Kesesuaian Lahan untuk Komoditas Pertanian Strategis Tingkat Semi Detail Skala 1:50 . 000. Bogor: Balai Besar Penelitian dan
Pengembangan Sumberdaya Lahan

Pertanian, Badan Penelitian dan Pengembangan Pertanian.

Zhang, M., \& He, Z. (2004). Long-term changes in organic carbon and nutrients of an Ultisol under rice cropping in southeast China. Geoderma, 118(3-4), 167-179. https://doi.org/10.1016/S0016-

7061(03)00191-5 